\title{
Recenzja książki: Валерий Соловей, Абсолютное оружие. Основы психологической войны и медиаманипулирования, Москва 2017, с. 320
}

W ciągu ostatnich lat odnotowuje się wzrost znaczenia badań politologicznych odnoszących się do wojny informacyjnej prowadzonej przez Federację Rosyjską. Wzmożona aktywność w tym zakresie jest spowodowana istniejącym od 2014 roku konfliktem na terenie Donbasu i poprzedzającą go aneksją Krymu. Dlatego należy docenić trud podjęty przez rosyjskiego badacza i teoretyka komunikacji społecznej Walerego Sołowieja ${ }^{1}$ przy rekonstrukcji medialnego obrazu świata w warunkach wojny informacyjnej wykreowanej przez władze Federacji Rosyjskiej. Tytuł recenzowanej monografiі Абсолютное оружие. Основы психологической войны и медиаманипулирования (pol. Najlepsza broń. Podstawy wojny psychologicznej i manipulacji medialnej) nie budzi zastrzeżeń pod względem rzeczowym, przestrzennym, jedynym mankamentem jest niezastosowanie kwantyfikatora czasowego. Temat publikacji jest generalnie odpowiednio ukonkretniony, zarazem informacyjnie nośny, poznawczo ciekawy i poprawny językowo. Przedmiot badań zawarty w tytule recenzowanej publikacji wywoływał zainteresowanie odbiorcy, uwypuklając istotę i kierunek badań zrealizowanych w trakcie eksploracji tematu. Został jasno sformułowany, pozwolił na precyzyjne określenie pola badawczego, dając czytelny zasięg poruszanego problemu. Brak zastosowania przez autora wyraźnego kwantyfikatora czasu w sformułowanym tytule publikacji, a przez to otwarta cezura czasowa sprzyjały badaniu przyję-

1 Walery Sołowiej. Były kierownik Katedry Public Relations w Państwowym Instytucie Stosunków Międzynarodowych w Moskwie. Absolwent Wydziału Historycznego Moskiewskiego Uniwersytetu Państwowego imienia Łomonosowa w Moskwie. Pracownik Fundacji imienia Michaiła Gorbaczowa. W 1995 odbył staż w London School of Economics. Autor i współautor czterech monografii, wielu artykułów naukowych z zakresu historii i polityki w Rosji, w tym artykułów prasowych, Мгимо университет, https://web.archive.org/web/20170429141704/http:/old.mgimo.ru/users/ document35523.phtml, inf. 23.10.2019. 
tego problemu we współcześnie zmieniających się na świecie warunkach politycznych i społecznych. Pomogły w tym przedłożone w publikacji egzemplifikacje odnoszące się do rzeczywistości politycznej prezentowanej w Federacji Rosyjskiej, na obszarze poradzieckim i w Stanach Zjednoczonych Ameryki. Uwagę natury ogólnej można sformułować do wyraźnego braku chronologii przywoływanych wydarzeń. Nie sprzyjało to przestrzeganiu reżimu pisarskiego, wyznaczonego linearnym porządkiem czasu.

W recenzowanej publikacji zabrakło wyraźnego określenia zastosowanych przez badacza metod i technik badawczych. Choć jak nadmieniono we wstępie pracy: „Oprócz badań na wydziale uniwersytetu posiadam również konta na portalach społecznościowych, przede wszystkim na Facebooku. Profil na Facebooku dowiódł, że nawet wykształceni i inteligentni ludzie są bezradni wobec profesjonalnie prowadzonych działań propagandowych" (wstęp). Zatem niejako ex post czytelnicy mogą domniemywać, że autor w swych dociekaniach badawczych zastosował technikę analizy zawartości mediów i krytyczną analizę dyskursu. Wykorzystano również semantyczno-logiczną analizę mediów w postaci portali społecznościowych, stron internetowych, agendy medialnej serwisów informacyjnych wraz z weryfikacją danych zawartych w dyskursie propagandowym.

W recenzowanej publikacji znalazły się objaśnienia głównych pojęć bezpośrednio związanych $\mathrm{z}$ tematem pracy. Najważniejszymi z nich były: wojna i wojna psychologiczna. Autor dokonał rozróżnienia przedstawionych pojęć, dokonując w rozdziale pierwszym krótkiej charakterystyki działań wojennych typu tradycyjnego, jak i w na gruncie prowadzonej wojny informacyjnej. Rosyjski badacz pisał: „Z wojną mamy do czynienia wtedy, gdy ludzie są zabijani, a obiekty niszczone ze względu na osiągnięcie niezrozumiałych, wątpliwych i czasami tylko uczciwych celów" (rozdział 1). Z kolei $\mathrm{w}$ wyjaśnieniu pojęcia wojny psychologicznej autor recenzowanej monografii odwoływał się do innego typu podejmowanych działań wojennych, stwierdzając: „W wojnie informacyjnej w odróżnieniu od zwykłej wojny ludzie nie tracą życia. Wojna psychologiczna zniekształca ludzką psychikę i deformuje intelekt. Zniszczenia w trakcie wojny psychologicznej nie obejmują miast i budynków, lecz system informacyjny państwa (rozdział 1). Autor działania podejmowane w ramach wojny psychologicznej rozpatrywał $\mathrm{w}$ dwóch aspektach. Po pierwsze w aspekcie informacyjno-technicznym. Konstytutywnymi cechami aspektu informacyjno-technicznego według autora były między innymi: zniszczenie i sabotaż systemów informacyjnych, elektroniki i logistyki przeciwnika i ochrona własnych systemów komunikacyjnych. Zjawisko to jest lepiej znane w literaturze przedmiotu jako cyberwojna.

Drugi aspekt obejmował kwestie informacyjno-psychologiczne, takie jak wpływ na społeczną i indywidualną świadomość i podświadomość strony przeciwnej w konflikcie przy jednoczesnej próbie ochrony własnej populacji (rozdział 1$)^{2}$. Autor dla uporządkowania wywodu naukowego sformułował dwie przejrzyste hipotezy badawcze brzmiące następująco: „Ważne jest, aby zrozumieć i zawsze pamiętać, że technologie

\footnotetext{
2 Więcej informacji zob. A. Kazimierska, W. Brzeziński, Strefy cyberwojny, Warszawa 2019.
} 
i techniki manipulacji posiadają uniwersalny charakter. Ich aplikacyjna wartość nie zależy od charakterystyki reżimu politycznego i stopnia swobody funkcjonowania mediów masowych”. W hipotezie drugiej stwierdził, że: „W pluralistycznym środowisku politycznym i medialnym do prowadzenia medialnej manipulacji wykorzystywane są najbardziej wyrafinowane metody i techniki wpływu politycznego" (wstęp). Autor we wstępie pracy nie sformułował pytań badawczych. Można to uznać jako zarzut formułowany pod jest adresem. Postawienie trafnych pytań badawczych w dużej mierze ułatwia przestrzeganie przyjętego reżimu pisarskiego. Powoduje również wewnętrzne uporząakowanie i koherentność treści przedkładanych w narracji naukowej.

W zamyśle rosyjskiego badacza recenzowana publikacja miała stanowić rozszerzenie cyklu autorskich wykładów adresowanych do słuchaczy studiów w Państwowym Instytucie Stosunków Międzynarodowych w Moskwie. Dlatego przyjęcie przez W. Sołowieja problemowej struktury publikacji należy uznać za trafne i godne pochwały. Publikacja składa się ze wstępu, 8 rozdziałów o charakterze merytorycznym i zakończenia. Zawartość poszczególnych rozdziałów stanowi 45 krótkich podrozdziałów. Poszczególne podrozdziały odzwierciedlają treści przekazywane przez rosyjskiego badacza studentom podczas prowadzonego autorskiego cyklu wykładów.

W rozdziale pierwszym pod tytułem Информационная война и медиаманипутирование: что, кто, с какой иелью, как (pol. Wojna informacyjna i medialna manipulacja co?, kto?, w jakim celu?, jak?), jak wspomniano powyżej, autor przedstawił definicję wojny i wojny informacyjnej, dokonał ich porównania i rozróżnienia konstytutywnych cech dwóch typów wojny. Według badacza pojęcie wojny informacyjnej pojawiło się w związku z prowadzonymi działaniami wojennymi na froncie I wojny światowej. Formułowanie założeń wojny informacyjnej nierozerwalnie wiąże się z pojęciem propagandy. W rozdziale opisano rozwój badań nad propagandą, nadmieniono, że popularne publikacje odnoszące się do działań propagandowych zaczęto publikować w latach 20. XX wieku. Autor zwrócił uwagę na instytucjonalizacje badań nad systemami propagandowymi i utworzenie w 1937 roku w Nowym Jorku Instytutu Badań nad Propagandą. W prowadzonym dyskursie naukowym autor sformułował główne cele wojny informacyjnej. Według badacza są nimi: „1) Próba wmówienia swoim stronnikom (partiom, liderom politycznym, że znajdują się po słusznej stronie prowadzonego konfliktu. 2) W prowadzonej wojnie informacyjnej należy również zdemoralizować stronę przeciwną doprowadzając ją do stanu dezorientacji i zagłady" (rozdział 1)3.

W podrozdziale pod tytułem Кто и для чего манипулирует (pol. Kto $i$ dlaczego manipuluje) autor starał się odpowiedzieć na postawione tytułowe pytanie. Za głównych manipulatorów - agendę medialną - uważa te osoby i grupy społeczne, które dzierżą władzę w mediach. Są to według autora właściciele medialnych koncernów. Za ważny podmiot polityczny starający się wpływać na politykę medialną Sołowiej uznał państwo jako podmiot stosunków międzynarodowych i rząd. Autor podjął również

3 Zob. A.D. Rotfeld, Rosja strategia oblężonej twierdzy, [w:] Obrazy Rosji i Rosjan w mediach, red. I. Hofman, J. Maguś, Lublin 2016, s. 13-54. 
próbę opisania wpływania na formułowanie przekazu medialnego przez władzę Federacji Rosyjskiej. Za datę przełomową $\mathrm{w}$ oddziaływaniu władz państwowych na środki masowego przekazu uznał rok 2000, gdy kadencja prezydenta Federacji Rosyjskiej Borysa Jelcyna nie została dokończona, a ustępującego prezydenta na urzędzie zastąpił Władimir Putin. Od tego momentu stan wpływania przez państwo na przekaz medialny traktowane jest w książce jako symbioza między instytucjami państwa a środkami masowego przekazu w Federacji Rosyjskiej. Za ważny element wpływu państwa na formułowanie przekazu medialnego uznano zjawisko autocenzury. Zupełnie inaczej autor przedstawiał sytuację manipulacji medialnym obrazem świata przez media zachodnie. Zwracał uwagę na zjawisko występowania pluralizmu w mediach, a także istnienie i możliwość wyboru przez odbiorców przekazów medialnych oferowanych przez zróżnicowane pod względem przekazywania treści stacje telewizyjne (rozdział 3).

Za ważny aspekt wojny informacyjnej autor uznał formułowanie przez media masowe przekazu dnia w serwisach informacyjnych ${ }^{4}$. Zwrócił uwagę na rolę psychiki człowieka w odbiorze prezentowanych przez media treści. W ocenie badacza percepcja człowieka jest bardzo ograniczona. W odbiorze treści w serwisach informacyjnych człowiek skupia się co najwyżej na odbiorze i przetwarzaniu informacji z 5 lub 8 najważniejszych tematów zawartych w informacyjnej agendzie dnia. Formułowanie agendy dnia jest uznawane $w$ recenzowanej publikacji za element walki politycznej prowadzonej przez polityków. Agenda medialna staje się również konstytutywnym elementem formułowania obrazu współczesnego świata. Za interesujący fragment opisywanego podrozdziału należy uznać przywołanie przykładów z polityki światowej obrazujących formułowanie przez media masowe przekazu dnia. Dobrym przykładem celowego przemilczenia tematu było przywołanie medialnego obrazu seksskandalu z udziałem byłego prezydenta Stanów Zjednoczonych Ameryki Billa Clintona. Jak pisał autor: „Aby odwrócić społeczną uwagę od sex skandalu z udziałem prezydenta jego administracja i sprzyjające jej środki masowego przekazu próbowały umniejszać znaczenie skandalu w przekazie medialnym" (rozdział 3). Za ważny poznawczo fragment recenzowanego podrozdziału należy uznać ten opisujący formułowanie agendy medialnej w telewizji Russian Today jako przykładu alternatywnego obrazu rzeczywistości politycznej prezentowanej na łamach rosyjskich mediów. Za trafne przykłady takiego postępowania należało uznać kwestie związane z przedstawianiem konfliktu w Gruzji, aneksji Krymu czy wojny w Donbasie.

W rozdziale czwartym Как подготовить сиену медиаспектакля (pol. Jak przygotować scenę medialnego spektaklu) autor na podstawie ustaleń poczynionych przez teoretyków propagandy Elliota Aronsona i Anthony’ego Pratkanisa przeanalizował strategie propagandowe przydatne przy formułowaniu medialnego obrazu świata. Aby opisać medialny obraz świata, użył za przywołanymi teoretykami terminu „sztuczka”

4 Zob. Agenda Setting Reading on media, public opinion and policymaking, eds D.L. Protess, New York-London 2009; J.W. Dearing, E.M. Rogers, Agenda Setting, bmw 1996; E. Nowak-Teter, Teoria agenda-setting a nowe media, „Studia Medioznawcze” 2016, nr 3. 
bądź „fortel”. Formułowanie propagandowego obrazu świata przyrównywał do prowadzenia działań wojennych. Rozróżnił przy tym cztery warstwy propagandowego wpływu: 1) formułowanie stereotypów i uprzedzeń; 2) wiara w źródła przekazu propagandowego; 3) dotarcie z przekazem do odbiorców komunikatu i przekonanie ich o swej bezalternatywnej wizji rzeczywistości.

W rozdziale piątym pod tytułem Доверься мне! (pol. Zaufaj mi) Sołowiej podkreślił rolę komunikatora w przekazie komunikatu do rozproszonego odbiorcy. Komunikatorem mogą być zarówno indywidualne, jak i zbiorowe podmioty komunikowania. Badacz zwrócił uwagę na związek między zaufaniem odbiorców komunikatów do komunikatora. W kwestii osiągnięcia zaufania odbiorców komunikowania politycznego autor odwoływał się do arystotelesowskiego pojęcia cnoty jako wartości nadrzędnej w polityce. Autor zdaje sobie sprawę, że na arenach politycznych współczesnego świata cnota i uczciwość wśród polityków staje się rzadkością. Zaproponował zatem, aby cechą dobrego komunikatora nie była cnota, lecz zdolność do wzbudzania jak najszerszego zaufania odbiorców formułowanych komunikatów.

W rozdziale szóstym pod tytułem Как включать и направлять человеческие эмоции (pol. Jak włączyć i kierować ludzkimi emocjami?) autor słusznie postawił tezę, że wiadomości $\mathrm{w}$ mediach wywołują określone emocje u odbiorcy. Wyszczególnił następujące typy emocji: strach, gniew, depresję i radość. Słusznie wskazał, że energetyczną mobilizację odbiorców komunikatów mogą wywoływać trzy z nich: strach, gniew i radość. Sołowiej wyszczególnił trzy typy strategii medialnych przydatnych do zarządzania ludzkimi emocjami. Są to: 1) poczucie triumfu lub jedności; 2) handel strachem;3) pobudzenie gniewu i wściekłości.

W rozdziale siódmym pod tytułem Реальные плоды виртуальных сражений (pol. Prawdziwe owoce wirtualnych bitew) opisano pojawienie się w dyskursie politycznym internetu i portali społecznościowych jako nowych i potężnych kanałów komunikacyjnych ludzkości. Opisano wykorzystanie nowych środków komunikacji masowej do celów politycznych w następujących aspektach: prowadzenie w państwie kampanii wyborczej, polityki zagranicznej jako polityki szczegółowej państwa, działań protestacyjnych i rewolucyjnych mogących nierzadko doprowadzić do konfliktu zbrojnego 5 .

W ostatnim rozdziale recenzowanej publikacji Какреагировать на манипулирование (pol. Jak reagować na manipulacje?) autor poszukiwał recepty na to, jak w najlepszy sposób odbiorcy komunikowania nie powinni poddać się manipulacji ze strony decydentów politycznych i mediów. Po pierwsze należało odrzucić błędne przekonanie, że jednostki nie są podatne na manipulowanie i że dana jednostka z pewnością nie zostanie wmanewrowana $\mathrm{w}$ działania manipulacyjne. $\mathrm{W}$ literaturze przedmiotu takie błędne przekonanie jest nazywane efektem strony trzeciej. Całość wywodu naukowego dopełnia zakończenie stanowiące posumowanie prowadzonych na łamach publikacji rozważań.

5 Zob. P.W. Singer, P. Warren, Nowy rodzaj wojny: media społecznościowe jako broń, tłum. S. Barankowski, Kraków 2019. 
W monografii spełniono wymogi rozłączności treści i rozdzielności tekstu. Jest ona napisana jasnym i klarownym językiem, który kompleksowo oddaje klimat badanego zagadnienia. Co ważne, wykorzystane zwroty zaczerpnięte z materiałów źródłowych (serwisów informacyjnych, Biblii) były właściwie zastępowane wypowiedziami in extenso na rzecz ich streszczeń, komentarzy i wyjaśnień zgodnie z konwencją pisarstwa naukowego. Sposób prowadzenia wywodu pozwolił na przeprowadzenie czynności dowodzenia naukowego, zastosowanie odpowiedniej argumentacji oraz dokonanie rekapitulacji przedłożonych przesłanek.

Przypisy w monografii są skonstruowane prawidłowo. W ośmiu rozdziałach zastosowano 65 przypisów, w konstrukcji których autor zastosował skróty rosyjskie (там же, pol., tamże). W monografii dominują przypisy bibliograficzne proste. W recenzowanym dziele uwidacznia się wyraźny brak przypisów polemicznych. Jest to istotny niedostatek, tym bardziej że w literaturze przedmiotu można znaleźć wiele wartościowych opracowań odnoszących się do problematyki wojny informacyjnej, propagandy politycznej ${ }^{6}$. Pewien zarzut można sformułować wobec niedoboru przypisów - 65 przypisów na 320 strony tekstu to stanowczo za mało. Niedostatek ten jest widoczny w poszczególnych rozdziałach. W bibliografii dominują zazwyczaj opracowania naukowe stanowiące monografie autorskie i zbiorowe. Autor powołał się zarówno na dorobek naukowy wypracowany zarówno przez rosyjskich badaczy, jak i zachodnich znawców problematyki.

W recenzowanej rozprawie przestrzegano reguł gramatycznych, składniowych, ortograficznych i interpunkcyjnych, co zdecydowało o wysokiej ocenie językowej dzieła pod względem redakcji językowej.

Za niewątpliwe zalety recenzowanej monografii należy uznać harmonijność i jasność wywodu badawczego oraz kompleksowe podejście do badanego problemu. Sprzyjała temu prawidłowa eksplikacja pojęć. Ciekawą kwestią była udana próba dekodowania specyficznych kodów językowych zawartych w prezentowanym dyskursie medialnym. Wysoko należy ocenić prawidłowy dobór przedkładanych przykładów dopełniających wywód naukowy i stanowiących interesujące studium przypadku. Za niewątpliwy plus monografii należało uznać próbę zachowania przez Sołowieja obiektywizmu naukowego, o który tak trudno u innych rosyjskich badaczy.

Mimo niewątpliwych zalet, jakie posiada monografia, nieodłącznym elementem recenzji jest konieczność odniesienia się do występujących wad. Można zaliczyć do nich brak sformułowania pytań badawczych, małą liczbę przypisów oraz ich skromność. W bibliografii powinno się znaleźć więcej opracowań naukowych.

Mimo wyszczególnionych, mało znaczących niedostatków recenzowaną monografię z czystym sumieniem można polecić wszystkim osobom interesującym się zjawiskiem manipulacji $\mathrm{w}$ mediach i polityce, istotą propagandy politycznej, analizą

6 Zob. J. Darczewska, Między jawna dezinformacją a niejawną praktyką: gry rosyjskich stużb, Warszawa 2019; L. Sykulski, Rosyjska geopolityka a wojna informacyjna, Warszawa 2019; Informacyjny wymiar wojny hybrydowej, red. M. Wrzosek, S. Markiewicz, Z. Modrzejewski, Warszawa 2019. 
Pobrane z czasopisma Wschód Europy http://journals.umcs.pl/we

Data: 26/04/2023 16:25:50

dyskursu medialnego, problematyką stosunków międzynarodowych ze szczególnym uwzględnieniem Federacji Rosyjskiej jako ważnego aktora współczesnych stosunków międzynarodowych. Recenzowane dzieło winno się stać obowiązkową lekturą dla studentów kierunków humanistycznych i społecznych, politologów, medioznawców, socjologów.

\section{Bibliografia}

Agenda Setting Reading on media, public opinion and policymaking, eds D.L. Protess, New York-London 2009.

Darczewska J., Między jawną dezinformacją a niejawną praktyką: gry rosyjskich służb, Warszawa 2019. Dearing J.W., Rogers E.M., Agenda Setting, bmw 1996.

Informacyjny wymiar wojny hybrydowej, red. M. Wrzosek, S. Markiewicz, Z. Modrzejewski, Warszawa 2019.

Kazimierska A., Brzeziński W., Strefy cyberwojny, Warszawa 2019.

Nowak-Teter E., Teoria agenda-setting a nowe media, „Studia Medioznawcze” 2016, nr 3.

Rotfeld A.D., Rosja - strategia oblężonej twierdzy, [w:] Obrazy Rosji i Rosjan w mediach, red. I. Hofman, J. Maguś, Lublin 2016.

Singer P.W., Warren P., Nowy rodzaj wojny: media społecznościowe jako broń, tłum. S. Barankowski, Kraków 2019.

Sykulski L., Rosyjska geopolityka a wojna informacyjna, Warszawa 2019. 